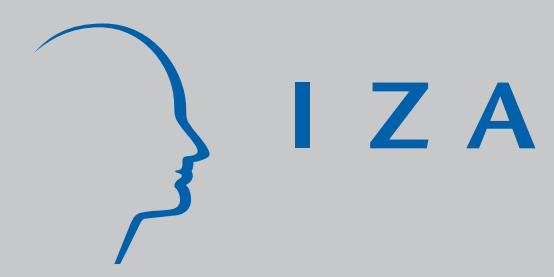

IZA DP No. 3886

So Many Rocket Scientists, So Few Marketing Clerks: Estimating the Effects of Economic Reform on Occupational Mobility in Estonia

Nauro F. Campos

Aurelij us Dabušinskas

December 2008 


\title{
So Many Rocket Scientists, So Few Marketing Clerks: Estimating the Effects of Economic Reform on Occupational Mobility in Estonia
}

\author{
Nauro F. Campos \\ Brunel University, \\ CEPR and IZA
}

Aurelijus Dabušinskas

Bank of Estonia

Discussion Paper No. 3886

December 2008

\author{
IZA \\ P.O. Box 7240 \\ 53072 Bonn \\ Germany \\ Phone: +49-228-3894-0 \\ Fax: +49-228-3894-180 \\ E-mail: iza@iza.org
}

Any opinions expressed here are those of the author(s) and not those of IZA. Research published in this series may include views on policy, but the institute itself takes no institutional policy positions.

The Institute for the Study of Labor (IZA) in Bonn is a local and virtual international research center and a place of communication between science, politics and business. IZA is an independent nonprofit organization supported by Deutsche Post World Net. The center is associated with the University of Bonn and offers a stimulating research environment through its international network, workshops and conferences, data service, project support, research visits and doctoral program. IZA engages in (i) original and internationally competitive research in all fields of labor economics, (ii) development of policy concepts, and (iii) dissemination of research results and concepts to the interested public.

IZA Discussion Papers often represent preliminary work and are circulated to encourage discussion. Citation of such a paper should account for its provisional character. A revised version may be available directly from the author. 
IZA Discussion Paper No. 3886

December 2008

\section{ABSTRACT}

\section{So Many Rocket Scientists, So Few Marketing Clerks: Estimating the Effects of Economic Reform on Occupational Mobility in Estonia*}

Why do workers change occupations? This paper investigates occupational mobility and its determinants following a large unexpected shock (communism's collapse in 1989.) Our calculations show that from 1989 to 1995 between 35 and 50 percent of Estonian workers changed occupations (classified at one- and four-digits, respectively). Among the main determinants of occupational mobility we find firm tenure, labour market experience and returns to alternative occupations. We investigate the role of gender and ethnicity and find strong results for the former, with mobility mainly driven by push factors for males (returns to current occupations) and by pull factors for females (returns to alternative occupations).

JEL Classification: J62, J63, J64, J23, C41, H53

Keywords: occupational mobility, human capital, transition economies

Corresponding author:

Nauro F. Campos

Department of Economics

Brunel University (West London)

Uxbridge, UB8 3PH

United Kingdom

E-mail: Nauro.Campos@brunel.ac.uk

\footnotetext{
* The authors would like to thank Tim Barmby, Peter Dolton, Oded Galor, Nandini Gupta, Geraint Johnes, Jan Kmenta, Hartmut Lehmann, Jan van Ours, James Robinson, Klara Sabirianova, Daniel Seidmann, Michael Spagat, Jan Svejnar, Katherine Terrell, Andrey Timofeev, Jonathan Wadsworth, two anonymous referees and seminar participants at the Universities of Bath, Brunel, London (Royal Holloway), Michigan, Newcastle and Reading, CERGE-EI (Prague), CEPR/ZEI Workshop on Labour Markets in Transition (Riga), ESRC/DESG Annual Meetings (Nottingham), CEPR/WDI Conference on Transition Economics (Portoroz), LACEA Meetings (Montevideo) and Royal Economic Society Meetings (Warwick) for valuable comments on earlier versions. We are also thankful to Mare Zaneva, Aavo Heinlo, Peter Luke and Kaja Söstra for assistance with the data. This paper benefited from financial support from the European Commission's Phare ACE Grant P978-085. The responsibility for all remaining errors is entirely ours.
} 


\section{Introduction}

The Berlin Wall fell in November 1989, the Soviet Union dissolved in December 1991. These collapses mark the end of the socialist experiment in Central Europe and in the Eastern Bloc. The experiment lasted for more than half a century and left a mixed legacy. One of the few inheritances from socialism that is widely perceived as positive is the labour force's high levels of educational attainment. However, and in spite of it, the composition of the human capital stock (in occupational terms) has proven inadequate to the needs of a modern market economy. There were too many rocket scientists, too many chess players, too many nuclear physicists, and not enough shopkeepers, not enough bankers, not enough marketing clerks. The transition entailed a change in the composition of the stock of human capital in terms of the shares of the various occupations. This process of occupational change has received insufficient attention thus far. This paper attempts to fill this gap.

We offer three motivations. The process of economic development in general, and that of transition in particular, necessarily involves occupational change. One of the least appreciated features of Lewis' seminal surplus labour model is that it is not sufficient for workers to move from the rural to the urban sector, they must change occupations. Campos and Coricelli (2002) summarize the first ten years of the transition in a set of seven stylized facts. One of these facts is that labour moved. Although workers did not seem to have moved geographically, they changed sectors and occupations in unprecedented scale. In order to comprehend the process of economic development in general, and that of transition in particular, we need to grasp the process of occupational change. A second motivation for studying occupational mobility is that it can throw light on the recent debate on the skill 
premium. ${ }^{1}$ One argument in this debate is that rising wage inequality in the last two decades in the U.S., U.K. and Canada is due to skill-biased technological change. Studying occupational mobility may be useful because one of its determinants is the transferability of skills across occupations. In this light, the premium may have risen for skills that are more easily transferable. A third and final motivation is that occupational change is at the heart of the allocation of talent problem. Murphy, Schleifer and Vishny (1991) and Acemoglu and Verdier (1998) emphasise that one of the most important aspects of the process of accumulation of human capital regards occupational choice. In particular, how society's pool of talent is allocated to entrepreneurial or rent-seeking activities is of fundamental importance vis-à-vis long-term growth. Murphy et al. (1991) put forward empirical evidence showing that countries with a larger proportion of engineers grow faster than countries with a larger proportion of lawyers.

The objective of this paper is twofold. The first is to provide a detailed description of the changing composition of the stock of human capital (in terms of the shares of the different occupational categories) and the second is to investigate the determinants of this process of occupational change. We choose Estonia for a number of reasons. Among transition economies, Estonia is considered a radical reformer and as such has pursued aggressive labour market policies that have fostered mobility. Moreover, for the early transition period, the Estonian Labour Force Survey (ELFS95) is arguably the best available database. It is unique in that it contains a retrospective section with detailed information on work histories that go back to communist times (until 1991, Estonia was one of the Soviet Republics).

Much recent economic research has focused on occupational mobility. In a seminal paper, Shaw (1984) argues that occupational mobility rates (that is, worker

\footnotetext{
${ }^{1}$ See Acemoglu (2002) and Katz and Autor (1999).
} 
flows between occupational categories) are very high in the United States. She estimates that in the 1970 s almost 50 percent of men aged 14 to 24 changed occupations. Parrado and Wolff (2007), Kambourov and Manovskii (2008), and Moscarini and Thomsson (2008) concur that occupational mobility is high in the U.S. and add that it has increased significantly since the 1970s. These authors estimate that approximately 15 percent of the U.S. population changed occupation in the 1970s with this share rising to about 20 percent in the 1990s. An important aspect of this literature is the connection between occupational mobility and economic turbulence, with the latter often modelled as oil shocks or as the popularization of computers in the workplace.

More recently, this line of inquiry has been extended to developing and transition countries, where economic turbulence is more severe and is also, some argue, of a qualitatively different nature from that observed in developed countries. One special source of turbulence has been experienced by a large group of economies, namely the former communist countries of Central and Eastern Europe. These have experienced a transition from a plan-based to a marked-based economy which involved the implementation of substantial economic and political reforms. In such contexts, Sabirianova (2002) finds that 30 percent of Russian workers switched occupations between 1991 and 1995, while Campos and Zlabkova (2001) find that approximately 35 percent of Hungarian workers changed occupations from 1989 to 1995 (both figures refer to the share of workers switching between occupational groups with the latter defined at the two-digit level.)

Most studies measure mobility focusing on upward occupational mobility (that is, "careers") in selected sub-samples (e.g., males). This paper tries to improve upon these previous efforts by identifying the main determinants of occupational mobility for the entire population examining downward as well as upward occupational 
mobility. With respect to the existing literature from transition economies, there are two main differences this paper brings about: here we examine the determinants of occupational mobility before and during the transition from communism (and we further differentiate between the time of political independence, 1991 in the case of Estonia, and that of the implementation of market-oriented reforms, which is 1993 in the Estonian case), and we investigate in detail ethnicity and gender differences in their roles as potential determinants of occupational mobility.

Our main findings are as follows. Our calculations reveal that between 35 and 50 percent of Estonian workers changed occupations between 1989 and 1995, this range depending on the level of aggregation used to classify occupations (one- and four-digit, respectively). ${ }^{2}$ In addition to firm tenure as a chief determinant of occupational mobility, our results also suggest that mobility is driven by push factors for males (the returns to current occupation) and by pull factors for females (returns to alternative occupations), with these results gaining (economic and statistical) importance as the transition proceeds and the market economy becomes more rooted. One important factor that differentiates occupation mobility among ethnic Estonians from that for non-Estonians is the returns to current occupations. These are found to be significant only for former group, that is, an increase in returns to current occupation significantly reduces the probability of occupational change for ethnic Estonians. Notice that this set of results is robust to various ways of controlling for worker heterogeneity, labour market conditions as well as to the complexity of the occupational switch.

2 It is difficult to identify exactly why the figures for Estonia are bigger than those for Hungary and Russia. We believe that one factor that plays a role in explaining these differences is that Estonia is often singled out among transition economies as one of the most radical "reformers," having adopted a very aggressive stance in terms of labor market policies from the outset. These are briefly reviewed in the next section (see Eamets, 1999, for a more detailed discussion of these reforms.) 
The paper is organized as follows. Section 2 provides background information on the implementation of economic reforms in Estonia. Section 3 focuses on the measurement of occupational mobility and distils the main stylized facts. Section 4 presents our estimation strategy. Section 5 discusses the main econometric results. Section 6 concludes.

\section{Economic Reforms and the Labour Market in Estonia}

The objective of this section is to describe the main macroeconomic developments in Estonia during the early transition years, with emphasis on the labour market and economic reforms. Estonia is a former Soviet Republic which regained independent in August 1991. It is the smallest of the three Baltic countries and one with important ethnic minorities. Until World War II, ethnic Estonians comprised more than $90 \%$ of the population, while as late as 1999, ethnic Estonians were less than $65 \%$ of the total population. Another important feature is that Estonians are not Slavs, having instead strong cultural and linguistic links with Scandinavia (especially Finland). Also of import is the fact that Estonia was chosen as testing ground for many of the reforms initiated by Gorbatchev in the 1980s, among other reasons, because of higher levels of development vis-à-vis the other Soviet republics. Yet, in international perspective, Estonian GDP per capita makes it an upper-middle income economy: Estonian per capita GDP was estimated at USD 3,480 (World Bank, 2000), slightly lower than that of Lebanon (USD 3,600) or Brazil (USD 4,420).

Table 1 shows the behaviour of some key macroeconomic aggregates during the Estonian transition. At the start, as elsewhere in the region, the collapse of the socialist system was followed by a substantial fall in real GDP, while the 
liberalization of prices in 1992 brought inflation to very high levels. ${ }^{3}$ Radical reform policies were implemented to cope with these issues (Haavisto, 1997). The most urgent task was perceived to be to control inflation and generate a stable macroeconomic environment. The authorities were convinced that macroeconomic stability was a necessary condition for a rapid development of the private sector. Relatively early macroeconomic stability and the recovery of growth were achieved by aggressively implementing tight monetary, fiscal and far-reaching structural reforms, especially after 1993. Consequently, Estonia was soon recognized as one of the most market-oriented economies in the region and, as such, it was the single FSU (Former Soviet Union) State selected to be among candidates for the "first wave" of EU accession.

Estonia was the first among the FSU countries to leave the ruble zone and introduce its own currency via a currency board arrangement in June 1992. In addition, a balanced government budget policy was chosen to guarantee that government's finances do not impinge on macroeconomic stability (Eamets, 1999). Table 1 shows that such policies were effective: from 1993 onwards the rate of inflation starts to decline sharply and the government balance remained either in surplus or in negligible deficit.

In late 1993, a number of structural reforms were undertaken to introduce market driven incentive structures and shore up the emergence of the private sector. They included budgetary tightening through the elimination of subsidies, removing of barriers to exit for state enterprises and to enter for new firms, and the starting of the process of privatization.

It did not take long until these structural reforms, privatization and enterprise restructuring, yielded the first positive results. The majority of small and medium size enterprises have been privatized by 1994. Soon thereafter, foreign direct investment has

\footnotetext{
${ }^{3}$ For a discussion of these issues see Eamets (1999), Berengaut (1998) and Haavisto (1997).
} 
surged and has amounted to as much as 10 per cent of GDP (Cornelius, 1995). Both developments might have been important in improving corporate governance. As a result, the signs of recovery in growth were visible as early as in 1994, when the contribution of the private sector to aggregate output already exceeded $50 \%{ }^{4}$

Table 1 also portrays the dramatic pattern of structural change that took place in Estonia. The table presents the dynamics of value-added shares in the three main sectors of the economy. Since 1990, the relative importance of agriculture halved, the economic contribution of industry declined by a third, while the contribution of the service sector skyrocketed. If the direction of these structural shifts does not come as a surprise (given the tendency for planned economies to inherit overly industrialized production systems), the speed of the Estonian adjustment is certainly impressive.

Structural changes of such scope require tremendous reallocation of productive resources. If a large share of inherited physical capital could and was simply written off by "destructive" market forces, it was the newly born labour market that was burdened by a major part of the resource reallocation process. This reallocation involved, in addition to the expected inflows and outflows, a change in the composition of the stock of human capital.

Table 2 summarises the labour market dynamics in the early Estonian transition. First notice that the decline in the labour force was large, by about 125 , 000 from 1989 to 1996 (15\% of the labour force in 1989$),{ }^{5}$ and that, during the same period, employment declined by almost as many as 200,000 or $23 \%$ of that in 1989 (for 1989-95 numbers, decline was of 180,000 or $22 \%$ of the original employment in

\footnotetext{
${ }^{4}$ The share of private sector in GDP was much smaller in Romania, Bulgaria and most of the former Soviet Union (cf. EBRD, 1999.)

5 The Estonian labour force continued to decline and the overall changes were surprisingly large. Notably, the participation rate declined from almost $77 \%$ in 1989 to $69 \%$ in 1995 to reach its all time low of $64 \%$ in 1999 . The employment rate dropped from $76 \%$ in 1989 to $62 \%$ in 1995 and reached $56 \%$ in 1999.
} 
1989.) Although a significant part of these changes was due to the emigration of ethnic Russians (Eamets 1999), those sharp declines in both participation and employment rates (by 9 and 15 percentage points respectively) indicate that transition had a rather dramatic real impact. Finally, the evolution of unemployment rate shows that the reemployment of labour resources, although relatively smooth at the beginning, became less so later on as the rate of unemployment climbed up gradually and reached 10 per cent by $1996 .^{6}$

One must also keep in mind that Estonian labour market policies were often characterized by an explicit intent to foster mobility across sectors and labour market states. For example, up to six months of free job training (including lessons in Estonian language and job searching techniques) were provided to all eligible workers, during training the worker received higher unemployment benefits than if unemployed and not attending training. Consequently, almost $40 \%$ of the unemployed Estonians chose to receive training, compared to less than $10 \%$ in Central Europe. Further, the unemployed could qualify for a start-up loan upon presentation of an approved business plan. Unemployment benefits in Estonia were set extremely low from the outset (about 10\% of wages), and the eligibility period was also comparatively short (six months). ${ }^{7}$

Table 3 describes sectoral changes in employment during 1990-94. Not surprisingly, employment behaviour mimicked the structural shifts in output described above. For example, by 1994 the agricultural and fishing sectors had released 44 per cent of their labour input, while manufacturing, another of the least successful sectors during transition, deployed almost 28 per cent of its 1989 labour input. In contrast, employment increased in various sectors, notably, financial

\footnotetext{
${ }^{6}$ See Eamets et al. (1999) for a discussion on the differences between LFS and registered unemployment statistics in Estonia.

7 See Noorkõiv et al. (1998) for a full discussion of these issues.
} 
intermediaries doubled their employment and wholesale and retail trade also increased significantly their employment levels in 1989-94.

A major test to Estonian macroeconomic stability came from the Russian crisis of August 1998. After four years of relatively high economic growth, the Estonian economy experienced a very sharp slowdown in economic activity (Table 1). Although overall GDP growth in 1998 amounted to 4.7 per cent, growth in the second half of the year was only 0.6 per cent. In 1999, however, real GDP shrank by 1.1 per cent, while the budget ended in a record high deficit of 4.7 per cent (Table 1). A major reason was the decline in the demand for exports: exports to Russia fell by more than 10\% in 1998, while in July 1999 they amounted to just half of the July 1998 level. Restrictive fiscal measures might also have contributed to the diminished domestic demand

In November 2000, the European Commission released reports on the progress of candidate countries towards EU accession. These reports provide a detailed evaluation of economic policies, reforms and economic performance of the candidate states. The report on Estonia contains an overall positive evaluation of the country's progress with structural reforms and placed it next to other most 'advanced' transition candidates: Poland, Slovenia and Hungary. The report concluded that "Estonia is a functioning market economy and should be able to cope with competitive pressure and market forces within the Union in the near term, provided that it stays with its present reform path" (EC, 2000, p.30). In May 2004, Estonia joined the European Union. 


\section{The Extent and Depth of Occupational Mobility: Measurement Issues}

In this section, we measure occupational mobility and describe its dynamics. The data source is the 1995 Estonian Labor Force Survey (ELFS95). The ELFS95 is representative $^{8}$ and wider than a normal labor force survey because it includes a retrospective section, covering the period 1989-1995 with information on full work histories (including wages). The data set is also unique because it covers the period before the start of the transition from centrally planned to a marker economy as well as three years into it. ${ }^{9}$ Respondents reported employment status monthly throughout the period, but reported wages only in the Fall of 1989, 1992, 1993 and 1994. From the outset, the first years of rapidly rising inflation 1990 and 1991 were excluded.

Table 4 shows our measures of the extent of occupational mobility in Estonia for four different levels of aggregation (see also Appendix Table I). The incidence of occupational mobility decreases with the level of aggregation. For instance, gross occupational flows at the four-digit level indicate that 47.1 percent of individuals who were employed in both 1988 and 1995 have changed occupations. This share declines to 35.2 percent at the one-digit level. Similar differences can be found in the yearly rates of change. Notice that the differences across levels of aggregation may seem too large because they also reflect the differences between the flows occurring "within groups" and "between groups." Consider the difference between the rates of gross

\footnotetext{
8 The sampling procedure used the 1989 Census to randomly draw one of every 100 persons in the 16-75 age group in 1995. Of the 10,955 people selected, 9,608 were interviewed. The difference is given by the following motives: failure to locate (557 people), emigration (404), death or illness (130) and refusal to participate (213) (Eamets, Kulikov and Philips, 1997).

9 The ELFS95 was prepared and carried out paying attention to well-known difficulties with retrospective data (Beckett et al., 2001). The responses regarding retrospective employment status were compared to the 1989 Census data. Most of the small discrepancies found could be explained by differences in the labor force definition. Although wage data could not be directly compared, the sample means of wages in the ELFS95 match wage data from the Estonian Statistical Office for all years (Noorkõiv et al., 1998). Last, but not least, data on economic activity and occupation were re-coded to the Soviet classification and the results were found to compare satisfactorily to the 1989 Census (Eamets et al., 1997).
} 
occupational flows of 9 percent and 8.4 percent in 1990-1991 obtained from four- and three-digit coding, respectively. The 0.6 percentage point difference may be due to occupational mobility within three-digit groups. Net occupational flows in Table 4 take into account only those changes that simultaneously alter the structural composition of occupations (in other words, the net measure neglects those parts of between-group flows that cancel out). Even accounting for these, we still find large differences across levels of aggregation.

While these results demonstrate that occupational change was massive in the early Estonian transition, they say little about its nature. How extensive were these occupational changes? One important aspect is to investigate whether or not those workers changing occupations also changed firm and sector (which are defined here as "complex changes" following Neal, 1999). We find that between 1989 and 1995, 69.1 percent of all occupational switches are complex, according to this definition. ${ }^{10}$ It is also worth noting that the share of complex switches rises rapidly in the first years of transition. ${ }^{11}$

After considering the magnitude and complexity of occupational switches, we now turn to their direction. Is the average switch one from occupations that require lots of schooling to ones that require little? Is the average switch one from high earnings occupations to ones with low earnings? In order to answer these questions we must first rank occupations. To do so, we construct two rankings: one is derived from an index of the amount of human capital needed for different occupations and

${ }^{10}$ Yearly estimates are not reported for the sake of space but are available from the authors upon request.

${ }^{11}$ Looking at the occupational dynamics from the ELFS95 sample in terms of one-digit level occupations, we see that four out of nine occupational groups have contracted during the transition in Estonia (Appendix Table I). These include plant and machine operators, clerks, professionals, and craft and related trade workers. The share of service workers and salesmen as well as that of senior officials and managers has expanded. This is perhaps what one should expect. Note, however, that elementary occupations have also gained importance. 
the other based on pure monetary returns. ${ }^{12}$ Table 5 shows the resulting rankings for each year. Although the correlation between the results from the two rankings is high (0.87 at the two-digit level for year 1994), there are important differences. In particular, the ranking of occupations by schooling requirement shows very little change from 1989 to 1994, while the ranking of occupations by earnings shows large changes. Table 6 shows that once each occupational switch is classified according to their direction (up or down these two rankings), they seem to be evenly divided between up and down the schooling ladder. Yet for the case of the earnings rankings, we find that the majority of the occupational changes involve moving downwards. ${ }^{13}$

\section{Occupational Mobility: Theoretical Framework and Estimation Strategy}

In this paper we use a modified version of Shaw's 1987 model for the study of occupational mobility. It states that the probability of changing between occupations $i$ and $j$ and/or employers $d$ and $e$ at time $t$ is given by:

$$
\mathrm{p}_{\mathrm{t}}^{\mathrm{ij}, \mathrm{de}}=\beta_{1} \operatorname{COST}_{\mathrm{t}}^{\mathrm{i}, \mathrm{j}}+\beta_{2} \operatorname{RTN}_{\mathrm{t}}^{\mathrm{i}}+\beta_{3} \operatorname{RTN}_{\mathrm{t}}^{\mathrm{j}}+\beta_{4} \operatorname{TENURE}_{\mathrm{t}}^{\mathrm{d}}+\boldsymbol{\beta}_{5} \mathbf{X}_{\mathbf{i}}+\varepsilon_{\mathrm{t}}^{\mathrm{i}, \mathrm{j}}
$$

where COST represents the value of lost returns to past occupational investment, $\mathrm{RTN}^{\mathrm{i}}$ is the present value of occupational investment in the current occupation, $\mathrm{RTN}^{\mathrm{i}}$ is the present value of occupational investment in alternative occupations, TENURE proxies for the level of current employer-specific investment, and $\mathbf{X}$ contains a set of variables to control for sector, ownership (state, cooperative, private) and location (town or country) of initial employment. This last set of variables mitigates omitted variables bias as they account for important features of the transition from plan to

12 We use the methodology proposed by Sicherman and Galor (1990, pp. 189-192).

${ }_{13}$ Parrado and Wolff (2007) find that " $45 \%$ of adult males changed 1-digit occupation between 1972 and 1974" in the U. S. and argue that these changes are associated with lower earnings (though this effect has lessened over time) as well as with tenure and potential experience. 
market, in particular, the relative decline of certain industries (manufacturing) and sectors (the public sector).

The hypotheses we want to test, following this model, are as follows: we expect that an increase in the present value of occupational investment in the current occupation would reduce the probability of changing occupations, while an increase in the present value of occupational investment in an alternative occupation would have the opposite effect. The increase in the value of lost returns to past occupational investments and an increase in job tenure are both expected to reduce the likelihood of switching occupations.

Although the intuition from this model is straightforward, the same is not true for the construction of its main variables (see Appendix Table II). More precisely, the emphasis is on distinguishing pull from push factors and it is clear that pull factors are more difficult to identify empirically. Returns to current and alternative occupations are estimated from a standard Mincerian wage regression. Returns to current occupation are from a regression of log wage on gender, level of education (seven categories), sector of activity, firm ownership, firm location, occupation dummies (two-digit level), age, and occupation dummies interacted with age. The returns to current occupation are calculated as the sum of the coefficient on the occupational dummy with the coefficient on age interacted with the relevant occupation times the age of the worker. The returns to alternative occupations are computed as the weighted average of the returns to all other occupations where the weights are the probability of actual occupational switches in the previous period. ${ }^{14}$

In addition, returns to current and alternative occupations were calculated for current as well as future wages. Current returns (to current and alternative

\footnotetext{
${ }^{14}$ The previous period depends on how we calculate returns. For what we call future returns it refers to the previous year, for what we call current returns the previous period depends on the year because as noted wage data for the two years of high inflation were not collected.
} 
occupations) are calculated using past wages, while future returns (to current and alternative occupations) assume that workers can forecast wages and thus use this information for deciding whether or not to change occupations. It is important to keep in mind that the latter may prove to be too strong an assumption, while at the same time it should somehow loose severity as the transition progresses. As an example, consider modeling occupational mobility in 1990. We draw upon 1989 wages to calculate returns to current and alternative occupations when following the first method, but we use 1992 wages when applying the second approach. To minimize endogeneity concerns, actual occupational switches of the previous period were used to weight the alternative returns in all cases. ${ }^{15}$

One of the most difficult variables in the model is the value of lost returns to past occupational investment. The literature recognizes these difficulties and one solution is to try to capture its inverse empirically. We follow Shaw (1987) in arguing that the latter can be satisfactorily proxied by those skills in the current occupation that can be easily transferred. When ranking two-digit qualifications, our skills transferability index (STI) does well in singling out basic education as the most transferable qualification and in identifying theology as the one, among the qualifications listed in the survey, which is most difficult to transfer across occupations. ${ }^{16}$

\section{The Determinants of Occupational Mobility}

The objective of this section is to investigate the determinants of occupational mobility in Estonia over the period 1989-1995. Table 7 shows our probit estimates of

\footnotetext{
15 We use 1989 actual switches to weight alternative returns when modeling occupational mobility in 1990.

${ }^{16}$ For the sake of space, a fuller discussion of STI is omitted. It is available from the authors upon request. Also notice that this is the only STI variant our data allow us to construct. Moreover, it does not perform well in the econometric analysis that follows.
} 
equation (1) using returns calculated on the basis of current wages (shown in Panel A) as well as returns calculated on the basis of future wages (in Panel B). For the sake of space, we only report the results obtained at ISCO 2-digit level (where ISCO stands for International Standard Classification of Occupations).

The one result that stands out as statistically significant for all years in the two panels is that for tenure, which is measured as the number of years the worker has spent with the current employer. The results show that it significantly lowers the probability of changing occupations: using the 1994 results, we find that ten more years of firm tenure reduce the probability of occupational change by 0.0229 or 2.29 percentage points (notice that tenure is measured as the number of years divided by 100.) It is also important to notice that this result obtains controlling for sector of employment, firm ownership, firm location and education level. Surprisingly, neither STI (skills transferability index) nor the measure of potential labour market experience plays a systematic role in explaining occupational mobility.

Yet some of the most striking results from Table 7 are those relating to the returns to current and alternative occupation. Panel A shows the stark contrast between the results for 1990 and those for 1994. Recall that, for 1990, the data still refer to the Soviet Republic of Estonia or, in other words, it refers to the probability of switching occupations under the socialist system. We should not expect strong support for the economic rationality we would find in a market economy. The sign on the coefficient on returns to alternative occupations suggests that, during communism in Estonia, an increase in those returns actually decreases the probability of switching occupations. ${ }^{17}$ Maybe workers could observe the erosion of

\footnotetext{
${ }^{17}$ In addition to the notion that workers may have been unable to react to wage differentials, another plausible explanation is that higher wages offered little incentive for change in an economy characterized by severe shortages and in which workers were more motivated by non-financial aspects of potential job moves (prestige, ease, non-pecuniary benefits, etc.)
} 
the relative returns to their current occupation, but they could not react. In stark contrast we show the results for 1994, after some years of intense economic reform. It can be also seen that the coefficient on the returns to current occupation is now statistically significant and carries the sign theory predicts: a decrease in these returns (everything else the same) translates into an increase in the probability of changing occupations. More specifically, and using the 1994 results, an increase in returns to current occupation by one standard deviation reduces the probability of occupational mobility by 0.011 or 1.1 percentage points (that is, $-0.053 * 0.2074$ ). Also notice that the coefficient on the returns to alternative occupation is now statistically significant and carries the predicted sign. An improvement in outside options significantly increases the probability of changing occupations: an increase in returns to alternative occupations in 1994 by one standard deviation increases the probability of occupational change by 0.0199 or 1.99 percentage points (that is, $0.148^{*} 0.1347$ ).

Our interpretation is that these results show the remarkable speed with which the market mechanism takes root (through the effective implementation of economic reforms): the returns to current and alternative occupations play, over these very few years, increasingly meaningful roles in explaining occupational change. One of the most commonly alleged reasons for studying transition economies is that they provide a natural laboratory for observing the emergence of a market mechanism. Table 7 shows this emergence of a market mechanism in concise fashion. ${ }^{18}$ For the first and last years of the two panels, the dummy variable for gender is statistically significant and suggests that, after taking into account a number of important determinants, females are still less likely than males to change occupations.

18 The effects of private ownership of the firm changes signs over time (from negative to positive) and that may be a reflection of transition itself. These results are available from the authors upon request. 
Panel B shows similar results but using future returns instead. Note that future returns are calculated for all years (for 1989, 1990, 1991 future wages are those of 1992 , for 1992 those of 1993 , and for 1993 of 1994). There a number of interesting results. Among the most robust determinants of occupational mobility we identify gender, tenure and experience. Women are less likely to switch occupations, as are those that have long job market experience and firm tenure. Although returns to current occupation always carry the expected negative sign, its coefficient is never statistically significant. As for returns to alternative occupations, it is rather intriguing that for 1989-1990 the coefficient has the "wrong" negative sign and is statistically significant. However, for the last year in our sample this coefficient has the expected positive sign and is statistically significant: an increase in returns to alternative occupation by one standard deviation increases the probability of occupational change by 0.015 or 1.15 percentage points (that is, $0.091 * 0.126$ ). One interesting observation is that private ownership turns from negative to positive over time, and that might be reflecting transition itself. Initially, if one was in the private sector perhaps it was less likely to move than from, say, the state sector. But later on, it is the private sector that constitutes the more dynamic part of economy, so movers tend to be from there.

These results were subjected to various sensitivity analyses. For example, we find that adding a dummy variable for Estonian nationality does not change any of our core results. Yet, when added to the wage regressions used to calculated returns to current and alternative occupations, such an "Estonian nationality dummy" becomes statistically significant and positive after 1992 (notice these findings are in line with the ones reported in Kroncke and Smith, 1999). ${ }^{19}$ The results presented

19 Kroncke and Smith (1999) offer econometric evidence that suggests that labor market discrimination in favor of Estonian nationals increased significantly throughout the transition. Estonia has a large Russian minority (as of late 1990s, only about two-thirds of the 
above are also robust to the addition of provincial employment rates (although these carry an unexpected positive sign). Last, but not least, when we run these probits separately for men and women, our results reveal substantial differences.

Table 8 assesses gender issues for the case of returns to current and alternative occupations on the basis of current wages (see Appendix Table III for these results using expected future wages). The process of occupational mobility seems to be driven by different reasons for men and women (with the exception of tenure that remains a chief determinant irrespectively). While for males, the main determinant seems to be that the negative effect of the returns to current occupation pushes them to change occupations, for females our results suggest that the fundamental issue is that the returns to alternative occupations seem to drive them to change occupations. Interestingly, the magnitude of these effects is also comparable. For males in 1994, an increase in returns to current occupation by one standard deviation reduces the probability of occupational change by 0.0225 or 2.25 percentage points (that is, $-0.11 * 0.2043$ ), while for females an increase in returns to alternative occupation by one standard deviation increases the probability of occupational change by 0.0204 or 2.04 percentage points (that is, $0.156 * 0.1305$ ). Moreover, these results are not inconsistent with the notion that the transition has been good to women by favoring sectors and occupations in which they tend to do well in advanced market economies. ${ }^{20}$ In sum, our results suggest that occupational mobility is driven by push factors for males and by pull factors for women, once the market mechanism starts to take root (that is for years 1993 and 1994). ${ }^{21}$

population are of Estonian origin).

20 Notice that these results also hold taking into account the effect of ethnicity (although the latter is seldom found to be a systematic determinant).

${ }^{21}$ These results for the returns on future wages are not qualitatively different. Firm tenure is, once again, the main determinant of occupational mobility. The results for our skills transferability index show that its coefficient is seldom statistically significant (for males) and it changes sign often. Notice, however, that using future wages as a basis to calculate returns 
Another important issue we investigate in this paper is whether ethnicity plays a systematic role in explaining differences in the patterns of occupational mobility. Table 9 examines these issues for the case of returns to current and alternative occupations on the basis of current wages, by splitting the sample according to whether or not the respondent is Estonian (non-Estonians are predominantly Russians.) There seems to be indeed important differences in the process of occupational mobility along ethnic lines: occupational mobility among Estonians seem to be driven by returns to alternative occupations (and to a lesser extent, returns to current occupation), experience and tenure, while among nonEstonians experience and tenure play a diminutive role, while the major role seems to be played by returns to alternative occupations. One important factor that seems to differentiate occupation mobility along ethnic lines is returns to current occupations, which are found to be significant only for Estonians (that is, an increase in returns to current occupation significantly reduces the probability of occupational change for ethnic Estonians). Notice that it is clear from the Table that it is a harder task to explain mobility among non-Estonians than among Estonians.

We have also tried to establish whether our results are robust to labor market and worker heterogeneity concerns. In order to address the first issue, we use a number of variables, such as regional (county) employment rates. This does not change the basic results discussed above. Our results are also robust to accounting for various aspects of worker heterogeneity. Specifically, they do not change if we include, as an explanatory variable, the number of occupations previously held, number of jobs previously held, the age of the individual, a dummy variable for

confirms the previous results for the males sub-sample that their process of occupational mobility seems driven (after the start of economic reforms) by declining returns to current occupation. Yet, the pull factor result for women looses statistical significance when we use future wages to calculate returns. The effect of Estonian ethnicity is still not statistically significant. These are available from the authors upon request. 
multiple-job holding, the yearly number and the cumulative number of jobs lost, and number of months of non-employment in the year of reference (up to a maximum of 11 months). ${ }^{22}$

Finally, another important form of sensitivity analysis is to investigate whether the results presented above are robust in light of occupational switches of different levels of complexity. A complex occupational switch is defined as a simultaneous change of occupation and firm (Neal, 1999). In Table 10 we estimate a multinomial logit model to identify the main factors that discriminate between intra- and inter-firm occupational mobility (following Sicherman and Galor, 1990). The three possible states are to change occupation and firm, to change occupation but stay in the same firm, and to not change occupation (but the worker may still change firm in this last case). The latter state is the reference category (as noted, about $60 \%$ of the occupational switches are complex as defined above).

The results from Table 10 show the importance of the complexity of occupational switches as our results seem driven by inter-firm mobility. ${ }^{23}$ Notice that, in terms of the determinants of occupational mobility, the results for inter-firm mobility in Table 10 are qualitatively the same as the results discussed above. Our multinomial logit estimates show that the dummy variable for females carries a negative sign and is statistically significant for all years and the same happens to the coefficient on firm tenure. Cleary, the relative importance of inter-firm mobility confirms this latter point. Our skills transferability index does not seem to play a systematic role in explaining the complexity of occupational switches either. It can also be seen the gradual change in the

\footnotetext{
${ }^{22}$ Notice that for a job lost we only consider the cases in which the reason for dismissal was one of the following: closing of enterprise, reorganization of enterprise, bankruptcy of enterprise, privatization of enterprise, dismissal initiated by the employer, and personnel reduction. These results are available from the authors upon request.

${ }^{23}$ We tested for the irrelevance of independent alternatives (IIA) using the Hausman and Small-Hsiao tests and both indicate that our design is appropriate.
} 
coefficients on the returns to current and alternative occupations, suggesting that this is indeed robust finding.

\section{Conclusions}

In this paper, we used data from a representative survey of Estonian workers between 1989 and 1995 (the Estonian Labour Force Survey 1995) to try to document and explain the process of occupational change. We find evidence that this process was substantial: according to our estimates, between 35 and $50 \%$ of all employed Estonian workers changed occupations in half a decade. Moreover, the bulk of these occupational switches happened in the first years, that is, very early in the transition.

We also investigated the determinants of this process of occupational mobility. We find that the main factors lowering the probability of a worker changing occupation are gender (female) and firm tenure. We find that although returns to current or alternative occupations do not seem to play a systematic role throughout, they do play over these few years increasingly important roles in explaining occupational change. In addition to firm tenure as a chief determinant of occupational mobility, our results also suggest that mobility is driven by push factors for males (the returns to current occupation) and by pull factors for females (returns to alternative occupations), with these results gaining (economic and statistical) importance as the transition proceeds, reforms are implemented and the market economy becomes more rooted. One important factor that differentiates occupation mobility along ethnic lines is returns to current occupations, which are found to be significant only for Estonians (that is, an increase in returns to current occupation significantly reduces the probability of occupational change for ethnic Estonians). 


\section{References}

Acemoglu, D., 2002. Technical change, inequality, and the labor market. Journal of Economic Literature XL, 7--72.

Acemoglu, D., Verdier, T., 1998. Corruption, property rights and the allocation of talent: a general equilibrium approach. Economic Journal 108, 1381--1403.

Beckett, M., Da Vanzo, J., Sastry, N., Panis, C., Peterson, C., 2001. The quality of retrospective data: an examination of long-term recall in a developing country. Journal of Human Resources 36, 593--625.

Berengaut, J., 1998. The Baltic countries: from economic stabilization to EU accession, Washington D.C., IMF Occasional Paper No. 173.

Campos, N., Coricelli, F., Growth in transition: what we know, what we don't, and what we should. Journal of Economic Literature XL, 793--836.

Campos, N., Žlábková, D., 2001. The wrong mix: a first look at occupational mobility during the Hungarian transition. Prague, CERGE-EI DP 59.

Dolton, P., Kidd, M., 1998. Job changes, occupational mobility and human capital acquisition: an empirical analysis. Bulletin of Economic Research 50, 265--295.

Eamets, R. (Ed.), 1999. Estonian Labour Market and Labour Market Policy. Ministry of Social Affairs of Estonia, Viljandi and Tallinn.

Eamets, R., Kulikov, D., Philips, K. (Eds.), 1997. Estonian Labour Force Survey 1995, Structural Changes in the Estonian Labour Market in 1989-1994. Statistical Office of Estonia, Tallinn and Viljandi.

EBRD, 1999. Transition Report 1999: Ten Years of Transition. European Bank for Reconstruction and Development, London.

Galor. O., Tsiddon, D., 1997. Technological progress, mobility, and economic growth. American Economic Review 87, 363--382.

Haavisto, T. (Ed.), 1997. The Transition to a Market Economy: Transformation and Reform in the Baltic States. Cheltenham, Edward Elgar.

Kambourov, G., Manovskii, I., 2008. Rising occupational and industry mobility in the United States: 1968-1993. International Economic Review 49, 41--79.

Katz, L., Autor, D. 1999. Changes in the wage structure and earnings inequality, in Ashenfelter, O., Card, D. (Eds.) Handbook of Labor Economics, vol 3b. North-Holland, Amsterdam.

Kroncke, C., Smith, K., 1999. The wage effects of ethnicity in Estonia. Economics of Transition 7:179--199. 
Moscarini, G., Thomsson, K., 2008. Occupational and job mobility in the US. Scandinavian Journal of Economics 109, 807-836.

McCall, B., 1990. Occupational matching: a test of sorts. Journal of Political Economy 90, 45--69.

Murphy, K., Schleifer, A., Vishny, R., 1991. The allocation of talent: implications for growth. Quarterly Journal of Economics 106, 503--530.

Neal, D., 1999. The complexity of job mobility among young men. Journal of Labor Economics 17, 237--261.

Noorkõiv, R., Orazem, P., Puur, A., Vodopivec, M., 1998. Employment and wage dynamics in Estonia. Economics of Transition 6, 481--503.

Parrado, E., Wolff, E., 2007. Occupational and industrial mobility in the United States. Labour Economics 14, 435-455.

Sabirianova, K., 2002. The great human capital reallocation: a study of occupational mobility in transitional Russia. Journal of Comparative Economics 30, 191--217.

Sicherman, N., Galor, O., 1990. A theory of career mobility. Journal of Political Economy 98, 169--192.

Shaw, K., 1984. A formulation of the earnings function using the concept of occupational investment. Journal of Human Resources 19, 319--340.

Shaw, K., 1987. Occupational change, employer change, and the transferability of skills. Southern Economic Journal 53, 702--719.

Svejnar, J., 1999. Labor markets in transitional Central and Eastern European Economies in Ashenfelter, O., Card, D. (Eds.) Handbook of Labor Economics, vol 3b. North-Holland, Amsterdam.

Statistical Office of Estonia, 1998. Estonian Labor Force Surveys 1995 and 1997. Statistical Office of Estonia, Tallinn.

Weber, R., Taube, G., 1999. On the fast track to EU Accession: macroeconomic effects and policy challenges for Estonia,” Washington D.C., IMF Working Paper 99/156.

World Bank, 2000. World Development Report 2000/2001. Oxford University Press, , Washington D.C. 
Table 1. Selected macroeconomic indicators, Estonia (1990-1999)

\begin{tabular}{lrrcccc}
\hline Year & Real GDP & Inflation & \multicolumn{2}{c}{ Share of } & sectoral value added, \% & Gov. balance, \\
& growth, \% & rate, \% & Agriculture & Industry & Services & \% of GDP \\
1990 & -8.1 & 23.1 & 16.6 & 43.5 & 39.9 &.. \\
1991 & -7.9 & 211.0 & 17.9 & 39.0 & 43.1 & 5.2 \\
1992 & -14.2 & 1076.0 & 13.1 & 34.7 & 52.2 & -0.3 \\
1993 & -8.5 & 89.8 & 11.0 & 31.1 & 57.9 & -0.7 \\
1994 & -1.8 & 47.7 & 10.2 & 30.4 & 59.4 & 1.3 \\
1995 & 4.3 & 28.9 & 8.1 & 28.7 & 63.2 & -1.2 \\
1996 & 4.0 & 23.1 & 7,5 & 28.0 & 65.1 & -1.5 \\
1997 & 10.6 & 11.2 & 6.9 & 27.3 & 65,8 & 2.0 \\
1998 & 4.7 & 8.1 & 6.3 & 27.6 & 66,1 & -0.3 \\
1999 & -1.1 & 3.3 & 5.7 & 25.3 & 69,0 & -4.7 \\
\hline
\end{tabular}

Source: WDI CD-ROM 1999; IMF (1999); EC 2000. 
Table 2. Selected labour market indicators, Estonia (1990-1999)

\begin{tabular}{crrrrrrrrrrrrr}
\hline & 1989 & 1990 & 1991 & 1992 & 1993 & 1994 & 1995 & 1996 & 1997 & 1998 & 1999 \\
Labor force & 842.6 & 831.7 & 819.8 & 794.8 & 757.8 & 749.4 & 726.9 & 717.6 & 717.7 & 706.4 & 696.3 \\
Employment & 837.9 & 826.4 & 807.8 & 765.7 & 708.1 & 692.6 & 656.1 & 645.6 & 648.4 & 640.2 & 614.0 \\
Unemployed & 4.7 & 5.3 & 12.0 & 29.1 & 49.6 & 56.7 & 70.9 & 71.9 & 69.4 & 70.2 & 86.2 \\
Inactive & 253.8 & 270.5 & 284.2 & 306.4 & 322.1 & 320.1 & 334.6 & 336.5 & 385.6 & 392.4 & 402.6 \\
Total & 1096.4 & 1102.3 & 1104.0 & 1101.2 & 1079.9 & 1069.4 & 1061.6 & 1054.1 & 1103.3 & 1102.8 & 1102.8 \\
Participation rate, \% & 76.9 & 75.5 & 74.3 & 72.2 & 70.2 & 70.1 & 68.5 & 68.1 & 65.1 & 64.4 & 63.5 \\
Employment rate, \% & 76.4 & 75.0 & 73.2 & 69.5 & 65.6 & 64.8 & 61.8 & 61.3 & 58.8 & 58.1 & 55.7 \\
Unemployment rate, \% & $(0.6)$ & 0.6 & 1.5 & 3.7 & 6.5 & 7.6 & 9.7 & 10.0 & 9.7 & 9.9 & 12.3 \\
\hline
\end{tabular}

Note: If not stated otherwise, figures refer to population aged 15 to 69 (from 1997 onwards, aged 15-74), annual averages, in thousands.

Source: Estonian Labour Force Survey 1995 and 1997, 1999, Statistical Office of Estonia. 
Table 3. Change in employment by economic activity, 1990-94

(compared with previous year, \%)

\begin{tabular}{lcccccc}
\hline \multicolumn{1}{c}{ Economic activity } & 1990 & 1991 & 1992 & 1993 & 1994 & $\begin{array}{c}\text { Change } \\
\text { Agriculture and forestry }\end{array}$ \\
& -2.2 & -5.6 & -12.0 & -20.2 & -13.6 & -44.0 \\
Fishing & -3.5 & -3.6 & -11.8 & -20.8 & -14.1 & -44.2 \\
Mining & -3.4 & 1.7 & 4.2 & -3.7 & 1.5 & 0.1 \\
Manufacturing & -2.9 & -3.3 & -7.8 & -13.2 & -4.1 & -28.0 \\
Electricity, gas and water & 0.9 & -0.8 & 0.6 & 5.7 & 8.8 & 15.8 \\
Construction & 2.7 & 0.8 & -6.2 & -10.5 & -3.1 & -15.8 \\
Wholesale and retail & 2.8 & 4.6 & 10.3 & 15.9 & 10.5 & 52.0 \\
trade & & & & & & \\
Hotels and restaurants & -6.2 & 6.8 & -4.8 & -0.8 & 11.1 & 5.0 \\
Transport and communic. & 2.8 & 0.6 & -6.0 & -0.4 & 0.5 & -2.8 \\
Financial intermediation & 7.6 & 14.4 & 22.2 & 16.4 & 21.7 & 113.1 \\
Real estate, etc. & -2.0 & -5.5 & -7.5 & 2.8 & 8.8 & -4.2 \\
Public administration, & -3.8 & 1.1 & 5.0 & 10.0 & 6.5 & 19.7 \\
etc. & & & & & & \\
Education & -2.3 & -1.4 & 2.7 & 3.9 & -0.6 & 2.1 \\
Health and social care & -0.4 & 1.7 & -3.4 & 1.4 & 1.2 & 0.5 \\
Other community services & 0.7 & -3.5 & -1.8 & 0.8 & 0.5 & -3.3 \\
Other &.. & 33.3 & 100.0 & 66.7 & -22.5 &.. \\
No response & 31.2 & 17.4 & 20.7 & 18.9 & 0.1 & 121.4 \\
\hline
\end{tabular}

Source: Eamets et al., 1997. 
Table 4. Measuring Occupational Mobility in Estonia: 1989-1995

\begin{tabular}{|c|c|c|c|c|}
\hline Period & $\begin{array}{c}\text { Gross } \\
\text { Occupational } \\
\text { Flows, \% }\end{array}$ & $\begin{array}{c}\text { Net } \\
\text { Occupational } \\
\text { Flows, \% }\end{array}$ & $\begin{array}{c}\text { Share of Net } \\
\text { Flows in } \\
\text { Gross, \% }\end{array}$ & $\begin{array}{c}\text { Number of } \\
\text { observations }\end{array}$ \\
\hline \multicolumn{5}{|c|}{ Four-Digit ISC088 Codes } \\
\hline 1988-1989 & 5.1 & 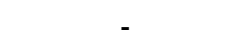 & - & 5906 \\
\hline 1989-1990 & 8.2 & - & - & 6049 \\
\hline $1990-1991$ & 9.0 & - & - & 5911 \\
\hline 1991-1992 & 13.4 & - & - & 5461 \\
\hline 1992-1993 & 15.3 & - & - & 5187 \\
\hline 1993-1994 & 13.6 & - & - & 5140 \\
\hline 1988-1995 & 47.1 & - & - & 4379 \\
\hline \multicolumn{5}{|c|}{ Three-Digit ISC088 Codes } \\
\hline $1988-1989$ & 4.7 & 1.5 & 31.5 & 5906 \\
\hline $1989-1990$ & 7.6 & 2.3 & 30.5 & 6049 \\
\hline $1990-1991$ & 8.4 & 3.1 & 37.1 & 5911 \\
\hline 1991-1992 & 12.5 & 4.2 & 33.8 & 5461 \\
\hline $1992-1993$ & 14.3 & 4.6 & 32.2 & 5187 \\
\hline 1993-1994 & 12.7 & 2.9 & 23.3 & 5140 \\
\hline $1988-1995$ & 44.0 & 17.1 & 38.8 & 4379 \\
\hline \multicolumn{5}{|c|}{ Two-Digit ISC088 Codes } \\
\hline 1988-1989 & 4.4 & 1.0 & 23.3 & 5906 \\
\hline 1989-1990 & 6.9 & 1.4 & 20.8 & 6049 \\
\hline $1990-1991$ & 7.5 & 2.1 & 27.4 & 5911 \\
\hline 1991-1992 & 11.5 & 3.0 & 26.5 & 5461 \\
\hline $1992-1993$ & 12.9 & 3.7 & 29.0 & 5187 \\
\hline 1993-1994 & 11.6 & 1.8 & 15.7 & 5140 \\
\hline $1988-1995$ & 40.3 & 14.3 & 35.4 & 4379 \\
\hline \multicolumn{5}{|c|}{ One-Digit ISCO88 Codes } \\
\hline 1988-1989 & 3.7 & 0.8 & 21.1 & 5906 \\
\hline $1989-1990$ & 5.9 & 1.1 & 18.7 & 6049 \\
\hline $1990-1991$ & 6.5 & 1.2 & 17.7 & 5911 \\
\hline 1991-1992 & 9.9 & 2.2 & 21.9 & 5461 \\
\hline $1992-1993$ & 11.0 & 2.8 & 25.9 & 5187 \\
\hline 1993-1994 & 10.0 & 1.2 & 11.9 & 5140 \\
\hline $1988-1995$ & 35.2 & 10.0 & 28.4 & 4379 \\
\hline \multicolumn{5}{|c|}{$\begin{array}{l}\text { Note: Gross occupational mobility is computed as a ratio of the number of employed } \\
\text { individuals who had different occupations in December of a current year and in December of } \\
\text { a base year to the total number of individuals employed in December of the base year. Net } \\
\text { flows are computed by summing the absolute values of changes in occupational share for all } \\
\text { occupations and dividing by two. ISCO } 88 \text { is the } 1988 \text { International Standard Classification of } \\
\text { Occupations (International Labour Office, 1990). }\end{array}$} \\
\hline
\end{tabular}


Table 5. Ranking of occupations (one-digit)

according to schooling and earnings ladders

Ranking of occupations (one-digit) according to schooling ladder

Occupation

$\begin{array}{cccc}\mathbf{1 9 8 9} & \mathbf{1 9 9 2} & \mathbf{1 9 9 3} & \mathbf{1 9 9 4} \\ 2 & 2 & 2 & 2 \\ 1 & 1 & 1 & 1 \\ 3 & 4 & 3 & 3 \\ 5 & 5 & 5 & 5 \\ 6 & 6 & 6 & 6\end{array}$

Legislators, senior officials and managers

Professionals

Technicians and associate professionals

Clerks

Service workers and shop and market sales

$\begin{array}{llll}9 & 9 & 10 & 9\end{array}$

Skilled agricultural and fishery workers

Craft and related trade workers

$\begin{array}{llll}7 & 7 & 7 & 7\end{array}$

Plant and machine operators and assemblers

Elementary occupations

Armed forces

$\mathrm{N}$

$\begin{array}{llll}8 & 8 & 8 & 10\end{array}$

$\begin{array}{llll}10 & 10 & 9 & 8\end{array}$

$\begin{array}{llll}4 & 3 & 4 & 4\end{array}$

$\begin{array}{llll}6428 & 5837 & 5664 & 5752\end{array}$

\section{Ranking of occupations (one-digit) according to earnings ladder}

\section{Occupation}

Legislators, senior officials and managers

Professionals

Technicians and associate professionals

Clerks

Service workers and shop and market sales

workers

Skilled agricultural and fishery workers

Craft and related trade workers

Plant and machine operators and assemblers

Elementary occupations

Armed forces

$\mathrm{N}$

Source: Authors' calculation.

\begin{tabular}{cccc}
$\mathbf{1 9 8 9}$ & $\mathbf{1 9 9 2}$ & $\mathbf{1 9 9 3}$ & $\mathbf{1 9 9 4}$ \\
2 & 1 & 1 & 1 \\
4 & 2 & 2 & 2 \\
6 & 3 & 4 & 4 \\
8 & 5 & 5 & 5 \\
7 & 7 & 8 & 9 \\
& & & \\
1 & 4 & 6 & 8 \\
5 & 6 & 7 & 6 \\
3 & 8 & 9 & 7 \\
10 & 10 & 10 & 10 \\
9 & 9 & 3 & 3 \\
6118 & 5481 & 5231 & 5286 \\
\hline
\end{tabular}


Table 6. Upward and downward occupational mobility

\begin{tabular}{|c|c|c|c|c|c|c|c|}
\hline & $1988-89$ & 1989-90 & 1990-91 & 1991-92 & 1992-93 & 1993-94 & 1988-95 \\
\hline & \multicolumn{7}{|c|}{ Schooling ladder } \\
\hline & \multicolumn{7}{|c|}{ Two-Digit Codes } \\
\hline Up, \% & 45.5 & 48.1 & 46.3 & 49.4 & 50.7 & 50.4 & 46.4 \\
\hline \multirow[t]{2}{*}{ Down, \% } & 54.5 & 51.9 & 53.7 & 50.6 & 49.3 & 49.6 & 53.6 \\
\hline & \multicolumn{7}{|c|}{ One-Digit Codes } \\
\hline $\mathrm{Up}, \%$ & 46.8 & 46.2 & 49.4 & 50.6 & 54.9 & 51.1 & 49.4 \\
\hline \multirow[t]{3}{*}{ Down, \% } & 53.2 & 53.8 & 50.6 & 49.4 & 45.1 & 48.9 & 50.6 \\
\hline & \multicolumn{7}{|c|}{ Earnings ladder } \\
\hline & \multicolumn{7}{|c|}{ Two-Digit Codes } \\
\hline Up, \% & 49.4 & 44.5 & 44.2 & 44.1 & 43.6 & 47.1 & 40.0 \\
\hline \multirow[t]{2}{*}{ Down, \% } & 50.6 & 55.5 & 55.8 & 55.9 & 56.4 & 52.9 & 56.0 \\
\hline & \multicolumn{7}{|c|}{ One-Digit Codes } \\
\hline Up, \% & 47.7 & 43.1 & 48.1 & 45.5 & 44.9 & 48.3 & 41.0 \\
\hline Down, \% & 52.3 & 57.9 & 51.9 & 54.5 & 55.1 & 51.7 & 59.0 \\
\hline
\end{tabular}

Note: See text for a discussion of how each ladder was estimated.

Source: Authors' calculation. 
Table 7. Determinants of Occupational Mobility in Estonia (Probit estimation, marginal effects at mean values reported)

\begin{tabular}{lccc}
\hline Panel A: Returns based on current wages & & \\
& 1990 & 1993 & 1994 \\
Returns to current & -.009 & -.025 & $-.053^{*}$ \\
occupation & $(.018)$ & $(.034)$ & $.028)$ \\
Returns to alternative & $-.087^{* * *}$ & -.023 & $.148^{* * *}$ \\
occupation & $(.025)$ & $(.037)$ & $(.051)$ \\
Skills transferability & -.013 & -.018 & -.023 \\
index & $(.017)$ & $(.021)$ & $(.019)$ \\
Dummy: Female=1 & $-.017^{* *}$ & -.015 & $-.035^{* * *}$ \\
& $(.006)$ & $(.009)$ & $(.009)$ \\
Experience & $.162^{* *}$ & .029 & $-.184^{* * *}$ \\
& $(.079)$ & $(.152$ & $(.063)$ \\
Firm tenure & $-.277^{* * *}$ & $-.251^{* * *}$ & $-.229^{* * *}$ \\
& $(.045)$ & $(.062)$ & $(.068)$ \\
Log likelihood & -1385.37 & -1686.69 & -1552.11 \\
Number of & 5843 & 4894 & 4751 \\
observati & & &
\end{tabular}

observations

Panel B: Returns based on future wages

\begin{tabular}{|c|c|c|c|c|c|}
\hline & 1990 & 1991 & 1992 & 1993 & 1994 \\
\hline Returns to current & .025 & -.019 & -.036 & .021 & -.036 \\
\hline occupation & $(.021)$ & $(.022)$ & $(.03)$ & (.03) & $(.023)$ \\
\hline Returns to alternative & $-.05 * * *$ & .029 & .054 & .068 & $.091 * *$ \\
\hline occupation & $(.018)$ & $(.024)$ & $(.036)$ & $(.051)$ & $(.044)$ \\
\hline Skills transferability & -.014 & $-.04 * * *$ & .005 & -.02 & -.024 \\
\hline index & $(.017)$ & $(.015)$ & $(.022)$ & $(.021)$ & $(.019)$ \\
\hline \multirow[t]{2}{*}{ Dummy: Female $=1$} & $-.012^{*}$ & $-.03 * * *$ & -.005 & -.012 & $-.03 * * *$ \\
\hline & $(.006)$ & $(.007)$ & $(.009)$ & $(.009)$ & $(.009)$ \\
\hline \multirow[t]{2}{*}{ Experience } & .042 & $-.17 * *$ & -.177 & -.088 & $-.29 * * *$ \\
\hline & $(.087)$ & $(.09)$ & $(.129)$ & $(.071)$ & $(.048)$ \\
\hline \multirow[t]{2}{*}{ Firm tenure } & $-.28 * * *$ & $-.21 * * *$ & $-.17 * * *$ & $-.26^{* * *}$ & $-.23 * * *$ \\
\hline & $(.046)$ & $(.049)$ & $(.059)$ & $(.062)$ & $(.069)$ \\
\hline Log likelihood & -1388.4 & -1421.3 & -1719.9 & -1686.5 & -1553.5 \\
\hline $\begin{array}{l}\text { Number of } \\
\text { observations }\end{array}$ & 5843 & 5685 & 5259 & 4894 & 4751 \\
\hline \multicolumn{6}{|c|}{$\begin{array}{l}\text { Note: Not shown: dummies for education (primary, basic, secondary, specialized secondary, higher and } \\
\text { academic degree), for sector (primary, secondary and tertiary), for ownership (private, state and co-operative), } \\
\text { and for location (town and countryside). Wage data for } 1991 \text { and } 1992 \text { were not collected because these were } \\
\text { years of high inflation. Occupational mobility basis for comparison is "not switching" (assigned value 0). } \\
\text { Standard errors (in parentheses) are heteroscedastic-consistent, *** denotes significant at the } 1 \% \text { level; ** } \\
\text { denotes significant at the } 5 \% \text { level; and * denotes significant at the } 10 \% \text { level. }\end{array}$} \\
\hline
\end{tabular}


Table 8. Determinants of Occupational Mobility in Estonia

Sensitivity Analysis Using Returns based on Current Wages to Assess Gender Issues (Probit estimation, marginal effects at mean values reported)

\begin{tabular}{|c|c|c|c|}
\hline \multicolumn{4}{|l|}{ Panel A: Males } \\
\hline \multirow{3}{*}{$\begin{array}{l}\text { Returns to current } \\
\text { occupation }\end{array}$} & 1990 & 1993 & 1994 \\
\hline & -.0293 & $-.11^{* *}$ & $-.11^{* * * *}$ \\
\hline & $(.031)$ & $(.04)$ & $(.041)$ \\
\hline \multirow{2}{*}{$\begin{array}{l}\text { Returns to alternative } \\
\text { occupation }\end{array}$} & $-.147 * * *$ & .031 & .099 \\
\hline & $(.039)$ & $(.05)$ & $(.071)$ \\
\hline \multirow{2}{*}{$\begin{array}{l}\text { Skills transferability } \\
\text { index }\end{array}$} & $-.462 * *$ & .014 & $-.054^{* *}$ \\
\hline & $(.023)$ & $(.031)$ & $(.027)$ \\
\hline \multirow[t]{2}{*}{ Experience } & $.351^{* * *}$ & .043 & $-.301 * * *$ \\
\hline & $(.107)$ & $(.223)$ & $(.105)$ \\
\hline \multirow[t]{2}{*}{ Firm tenure } & $-.354 * * *$ & $-.278^{* * *}$ & $-.273 * * *$ \\
\hline & $(.069)$ & $(.092)$ & $(.097)$ \\
\hline \multirow[t]{2}{*}{ Dummy: Estonian=1 } & -.008 & $.028 * *$ & $.034^{* *}$ \\
\hline & $(.010)$ & $(.014)$ & $(.014)$ \\
\hline Log likelihood & -740.15 & -948.95 & -910.49 \\
\hline $\begin{array}{l}\text { Number of } \\
\text { observations }\end{array}$ & 2979 & 2603 & 2534 \\
\hline \multicolumn{4}{|l|}{ Panel B: Females } \\
\hline & 1990 & 1993 & 1994 \\
\hline \multirow{2}{*}{$\begin{array}{l}\text { Returns to current } \\
\text { occupation }\end{array}$} & .001 & .059 & .015 \\
\hline & $(.022)$ & $(.047)$ & $(.039)$ \\
\hline \multirow{2}{*}{$\begin{array}{l}\text { Returns to alternative } \\
\text { occupation }\end{array}$} & -.013 & $.088^{*}$ & $.156^{* *}$ \\
\hline & $(.032)$ & $(.051)$ & $(.066)$ \\
\hline \multirow{2}{*}{$\begin{array}{l}\text { Skills transferability } \\
\text { index }\end{array}$} & .022 & $-.049 *$ & .012 \\
\hline & $(.027)$ & $(.028)$ & $(.026)$ \\
\hline \multirow[t]{2}{*}{ Experience } & -.064 & .074 & -.062 \\
\hline & $(.108)$ & $(.211)$ & $(.091)$ \\
\hline \multirow[t]{2}{*}{ Firm tenure } & $-.195^{* * *}$ & $-.228 * * *$ & $-.193^{* *}$ \\
\hline & $(.060)$ & $(.081)$ & $(.089)$ \\
\hline \multirow[t]{2}{*}{ Dummy: Estonian=1 } & -.008 & .007 & .018 \\
\hline & $(.009)$ & $(.013)$ & $(.012)$ \\
\hline \multirow{2}{*}{$\begin{array}{l}\text { Log likelihood } \\
\text { Number of } \\
\text { observations }\end{array}$} & -624.58 & -718.99 & -623.88 \\
\hline & 2849 & 2285 & 2197 \\
\hline \multicolumn{4}{|c|}{$\begin{array}{l}\text { Note: Not shown: dummies for education (primary, basic, secondary, specialized secondary, higher and } \\
\text { academic degree), for sector (primary, secondary and tertiary), for ownership (private, state and co-operative), } \\
\text { and for location (town and countryside). Wage data for } 1991 \text { and } 1992 \text { were not collected because these were } \\
\text { years of high inflation. Occupational mobility basis for comparison is "not switching" (assigned value } 0 \text { ). } \\
\text { Standard errors (in parentheses) are heteroscedastic-consistent, *** denotes significant at the } 1 \% \text { level; ** } \\
\text { denotes significant at the } 5 \% \text { level; and * denotes significant at the } 10 \% \text { level. }\end{array}$} \\
\hline
\end{tabular}


Table 9. Determinants of Occupational Mobility in Estonia Sensitivity Analysis Using Returns based on Current Wages to Assess Ethnicity Issues (Probit estimation, marginal effects at mean values reported)

\begin{tabular}{|c|c|c|c|}
\hline \multicolumn{4}{|l|}{ Panel A: Estonians } \\
\hline \multirow{3}{*}{ Returns to current occupation } & 1990 & 1993 & 1994 \\
\hline & -0.008 & -0.049 & $-0.073^{* *}$ \\
\hline & $(0.022)$ & $(0.042)$ & $(0.037)$ \\
\hline \multirow{2}{*}{$\begin{array}{l}\text { Returns to alternative } \\
\text { occupation }\end{array}$} & $-0.099 * * *$ & -0.028 & $0.134^{* *}$ \\
\hline & $(0.033)$ & $(0.046)$ & $(0.065)$ \\
\hline \multirow[t]{2}{*}{ Skills transferability index } & -0.026 & 0.008 & -0.027 \\
\hline & $(0.020)$ & $(0.028)$ & $(0.024)$ \\
\hline \multirow[t]{2}{*}{ Dummy: Female $=1$} & $-0.021 * *$ & $-0.029^{* *}$ & $-0.042^{* * *}$ \\
\hline & $(0.008)$ & $(0.012)$ & $(0.012)$ \\
\hline \multirow{2}{*}{ Experience } & 0.160 & 0.153 & $-0.266^{* * *}$ \\
\hline & $(0.103)$ & $(0.189)$ & $(0.082)$ \\
\hline \multirow{2}{*}{ Firm tenure } & $-0.228 * * *$ & $-0.206 * * *$ & $-0.264 * * *$ \\
\hline & $(0.056)$ & $(0.075)$ & $(0.086)$ \\
\hline Log pseudo-likelihood & -853.2 & -1134.5 & -1080.2 \\
\hline Number of observations & 3762 & 3202 & 3157 \\
\hline \multicolumn{4}{|l|}{ Panel B: Non-estonians } \\
\hline \multirow{3}{*}{ Returns to current occupation } & 1990 & 1993 & 1994 \\
\hline & -0.004 & 0.012 & -0.036 \\
\hline & $(0.033)$ & $(0.053)$ & $(0.043)$ \\
\hline Returns to alternative & $-0.066^{*}$ & -0.016 & $0.140^{*}$ \\
\hline Occupation & $(0.036)$ & $(0.058)$ & $(0.075)$ \\
\hline \multirow[t]{2}{*}{ Skills transferability index } & 0.026 & $-0.057 *$ & -0.014 \\
\hline & $(0.031)$ & $(0.032)$ & $(0.030)$ \\
\hline \multirow[t]{2}{*}{ Dummy: Female $=1$} & -0.005 & 0.013 & $-0.026^{*}$ \\
\hline & $(0.012)$ & $(0.015)$ & $(0.014)$ \\
\hline \multirow[t]{2}{*}{ Experience } & 0.156 & -0.164 & -0.075 \\
\hline & $(0.119)$ & $(0.224)$ & $(0.098)$ \\
\hline \multirow[t]{2}{*}{ Firm tenure } & $-0.364^{* * *}$ & $-0.355^{* * *}$ & -0.176 \\
\hline & $(0.081)$ & $(0.108)$ & $(0.108)$ \\
\hline Log pseudolikelihood & -523.2 & -541.6 & -462 \\
\hline Number of observations & 2072 & 1692 & 1594 \\
\hline \multicolumn{4}{|c|}{$\begin{array}{l}\text { Note: Not shown: dummies for education (primary, basic, secondary, specialized secondary, higher and } \\
\text { academic degree), for sector (primary, secondary and tertiary), for ownership (private, state and co-operative), } \\
\text { and for location (town and countryside). Wage data for } 1991 \text { and } 1992 \text { were not collected because these were } \\
\text { years of high inflation. Occupational mobility basis for comparison is "not switching" (assigned value 0). } \\
\text { Standard errors (in parentheses) are heteroscedastic-consistent, } * * * \text { denotes significant at the } 1 \% \text { level; ** } \\
\text { denotes significant at the } 5 \% \text { level; and * denotes significant at the } 10 \% \text { level. }\end{array}$} \\
\hline
\end{tabular}


Table 10

\begin{tabular}{|c|c|c|c|c|c|c|c|c|c|c|c|c|c|c|c|}
\hline \multicolumn{16}{|c|}{$\begin{array}{c}\text { Determinants of Occupational Mobility (Multinomial Logit); } \\
\text { Sensitivity Analysis Using Returns based on Future Wages to Assess Complexity (Intra- and Inter-firm mobility); } \\
\text { Marginal effects (at sample means) }\end{array}$} \\
\hline & $\begin{array}{c}\text { No } \\
\text { mobility }\end{array}$ & $\begin{array}{c}1990 \\
\text { Interfirm } \\
\text { mobility }\end{array}$ & $\begin{array}{l}\text { Intrafirm } \\
\text { mobility }\end{array}$ & $\begin{array}{c}\text { No } \\
\text { mobility }\end{array}$ & $\begin{array}{c}1991 \\
\text { Interfirm } \\
\text { mobility }\end{array}$ & $\begin{array}{l}\text { Intrafirm } \\
\text { mobility }\end{array}$ & $\begin{array}{c}\text { No } \\
\text { mobility }\end{array}$ & $\begin{array}{c}1992 \\
\text { Interfirm } \\
\text { mobility }\end{array}$ & $\begin{array}{l}\text { Intrafirm } \\
\text { mobility }\end{array}$ & $\begin{array}{c}\text { No } \\
\text { mobility }\end{array}$ & $\begin{array}{c}1993 \\
\text { Interfirm } \\
\text { mobility }\end{array}$ & $\begin{array}{l}\text { Intrafirm } \\
\text { mobility }\end{array}$ & $\begin{array}{c}\text { No } \\
\text { mobility }\end{array}$ & $\begin{array}{c}1994 \\
\text { Interfirm } \\
\text { mobility }\end{array}$ & $\begin{array}{c}\text { Intrafirm } \\
\text { mobility }\end{array}$ \\
\hline Returns to current occupation & $\begin{array}{l}-0.015 \\
(0.017)\end{array}$ & $\begin{array}{c}0.014 \\
(0.015)\end{array}$ & $\begin{array}{c}0.002 \\
(0.008)\end{array}$ & $\begin{array}{c}0.019 \\
(0.019)\end{array}$ & $\begin{array}{l}-0.013 \\
(0.018)\end{array}$ & $\begin{array}{l}-0.006 \\
(0.006)\end{array}$ & $\begin{array}{c}0.035 \\
(0.028)\end{array}$ & $\begin{array}{l}-0.020 \\
(0.026)\end{array}$ & $\begin{array}{l}-0.015 \\
(0.011)\end{array}$ & $\begin{array}{l}-0.015 \\
(0.027)\end{array}$ & $\begin{array}{l}0.012 \\
(0.027)\end{array}$ & $\begin{array}{c}0.003 \\
(0.007)\end{array}$ & $\begin{array}{l}0.037^{*} \\
(0.021)\end{array}$ & $\begin{array}{l}-0.036^{*} \\
(0.019)\end{array}$ & $\begin{array}{l}-0.001 \\
(0.009)\end{array}$ \\
\hline $\begin{array}{l}\text { Returns to alternative } \\
\text { occupation }\end{array}$ & $\begin{array}{c}0.039 * * * \\
(0.014)\end{array}$ & $\begin{array}{l}-0.041^{* * *} \\
(0.012)\end{array}$ & $\begin{array}{c}0.002 \\
(0.007)\end{array}$ & $\begin{array}{l}-0.026 \\
(0.021)\end{array}$ & $\begin{array}{c}0.017 \\
(0.020)\end{array}$ & $\begin{array}{c}0.009 \\
(0.006)\end{array}$ & $\begin{array}{l}-0.051^{*} \\
(0.031)\end{array}$ & $\begin{array}{c}0.023 \\
(0.028)\end{array}$ & $\begin{array}{l}0.028 * * \\
(0.014)\end{array}$ & $\begin{array}{l}-0.054 \\
(0.045)\end{array}$ & $\begin{array}{l}0.041 \\
(0.044)\end{array}$ & $\begin{array}{c}0.013 \\
(0.013)\end{array}$ & $\begin{array}{l}-0.076^{*} \\
(0.039)\end{array}$ & $\begin{array}{l}0.086 * * \\
(0.037)\end{array}$ & $\begin{array}{l}-0.010 \\
(0.015)\end{array}$ \\
\hline Skills transferability index & $\begin{array}{c}0.003 \\
(0.014)\end{array}$ & $\begin{array}{l}0.000 \\
(0.012)\end{array}$ & $\begin{array}{l}-0.003 \\
(0.008)\end{array}$ & $\begin{array}{l}0.025^{* *} \\
(0.012)\end{array}$ & $\begin{array}{c}-0.024 * * \\
(0.012)\end{array}$ & $\begin{array}{l}-0.001 \\
(0.005)\end{array}$ & $\begin{array}{l}-0.012 \\
(0.022)\end{array}$ & $\begin{array}{l}0.005 \\
(0.020)\end{array}$ & $\begin{array}{l}0.008 \\
(0.010)\end{array}$ & $\begin{array}{c}0.019 \\
(0.018)\end{array}$ & $\begin{array}{l}-0.021 \\
(0.017)\end{array}$ & $\begin{array}{c}0.002 \\
(0.007)\end{array}$ & $\begin{array}{l}0.017 \\
(0.017)\end{array}$ & $\begin{array}{l}-0.017 \\
(0.015)\end{array}$ & $\begin{array}{c}0.001 \\
(0.007)\end{array}$ \\
\hline Dummy: Female $=1$ & $\begin{array}{l}0.010^{*} \\
(0.005)\end{array}$ & $\begin{array}{c}-0.013 * * * \\
(0.005)\end{array}$ & $\begin{array}{c}0.003 \\
(0.003)\end{array}$ & $\begin{array}{c}0.024 * * * \\
(0.006)\end{array}$ & $\begin{array}{c}-0.024 * * * \\
(0.006)\end{array}$ & $\begin{array}{l}-0.001 \\
(0.002)\end{array}$ & $\begin{array}{l}0.007 \\
(0.008)\end{array}$ & $\begin{array}{l}-0.014 * \\
(0.008)\end{array}$ & $\begin{array}{l}0.007 * * \\
(0.003)\end{array}$ & $\begin{array}{l}0.015^{*} \\
(0.009)\end{array}$ & $\begin{array}{c}-0.023 * * * \\
(0.008)\end{array}$ & $\begin{array}{c}0.008 * * * \\
(0.003)\end{array}$ & $\begin{array}{c}0.032 * * * \\
(0.009)\end{array}$ & $\begin{array}{c}-0.027 * * * \\
(0.008)\end{array}$ & $\begin{array}{l}-0.004 \\
(0.003)\end{array}$ \\
\hline Experience & $\begin{array}{l}-0.035 \\
(0.068)\end{array}$ & $\begin{array}{c}0.076 \\
(0.059)\end{array}$ & $\begin{array}{l}-0.040 \\
(0.034)\end{array}$ & $\begin{array}{l}0.137 * \\
(0.076)\end{array}$ & $\begin{array}{l}-0.121^{*} \\
(0.073)\end{array}$ & $\begin{array}{l}-0.017 \\
(0.020)\end{array}$ & $\begin{array}{c}0.157 \\
(0.114)\end{array}$ & $\begin{array}{l}-0.088 \\
(0.108)\end{array}$ & $\begin{array}{l}-0.069^{*} \\
(0.041)\end{array}$ & $\begin{array}{c}0.091 \\
(0.065)\end{array}$ & $\begin{array}{l}-0.108^{*} \\
(0.063)\end{array}$ & $\begin{array}{c}0.017 \\
(0.015)\end{array}$ & $\begin{array}{c}0.261 * * * \\
(0.044)\end{array}$ & $\begin{array}{c}-0.257 * * * \\
(0.041)\end{array}$ & $\begin{array}{l}-0.003 \\
(0.016)\end{array}$ \\
\hline Firm tenure & $\begin{array}{c}0.292 * * * \\
(0.038) \\
\end{array}$ & $\begin{array}{c}-0.310^{* * *} \\
(0.035) \\
\end{array}$ & $\begin{array}{c}0.018 \\
(0.016) \\
\end{array}$ & $\begin{array}{c}0.232 * * * \\
(0.047) \\
\end{array}$ & $\begin{array}{c}-0.236 * * * \\
(0.046) \\
\end{array}$ & $\begin{array}{c}0.004 \\
(0.010) \\
\end{array}$ & $\begin{array}{c}0.211 * * * \\
(0.057) \\
\end{array}$ & $\begin{array}{c}-0.239 * * * \\
(0.055) \\
\end{array}$ & $\begin{array}{c}0.028 \\
(0.018) \\
\end{array}$ & $\begin{array}{c}0.293 * * * \\
(0.060) \\
\end{array}$ & $\begin{array}{c}-0.309 * * * \\
(0.059) \\
\end{array}$ & $\begin{array}{r}0.016 \\
(0.013) \\
\end{array}$ & $\begin{array}{c}0.278^{* * *} \\
(0.072) \\
\end{array}$ & $\begin{array}{c}-0.278^{* * *} \\
(0.071) \\
\end{array}$ & $\begin{array}{c}0.000 \\
(0.019)\end{array}$ \\
\hline $\begin{array}{l}\text { Log pseudo-likelihood } \\
\text { Number of observations }\end{array}$ & & $\begin{array}{c}-1576.8 \\
5848\end{array}$ & & & $\begin{array}{l}-1572.8 \\
5690\end{array}$ & & & $\begin{array}{l}-1962 \\
5259\end{array}$ & & & $\begin{array}{c}-1889.2 \\
4898\end{array}$ & & & $\begin{array}{c}-1730.4 \\
4751\end{array}$ & \\
\hline
\end{tabular}

Notes: Not shown: Not shown: dummies for education (primary, basic, secondary, specialized secondary, higher and academic degree), for sector (primary, secondary and tertiary), for ownership (private, state and co-operative), and for location (town, countryside and abroad). Occupational mobility basis for comparison is not switching occupations or firms. Interfirm mobility stands for change in occupation and change in firm. Intrafirm mobility stands for change in occupation in same firm. ${ }^{* *}$ denotes significant at the $1 \%$ level; $* *$ denotes significant at the $5 \%$ level;

and * denotes significant at the $10 \%$ level. 


\section{Appendix Table I}

The Extent of Occupational Mobility in Estonia, 1989-1995:
Percentage Change of Occupational Shares

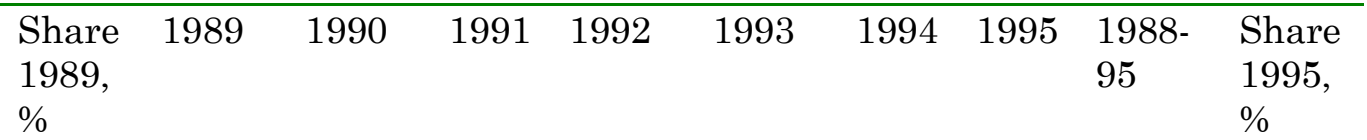

Change in shares, \%

\begin{tabular}{|c|c|c|c|c|c|c|c|c|c|c|}
\hline Armed forces & 0.1 & -26.7 & 18.2 & 7.7 & 0.0 & 78.6 & 12.0 & 14.3 & 113.3 & 0.32 \\
\hline $\begin{array}{l}\text { Legislators, senior } \\
\text { officials and managers }\end{array}$ & 11.5 & -1.4 & 0.3 & 0.8 & 6.1 & 6.4 & 1.4 & 1.3 & 15.4 & 13.4 \\
\hline Professionals & 13.6 & -1.8 & -1.8 & -2.5 & 2.4 & -4.0 & -4.2 & 3.0 & -8.8 & 12.6 \\
\hline $\begin{array}{l}\text { Technicians and } \\
\text { associate professionals }\end{array}$ & 10.9 & -0.1 & -1.7 & 0.8 & 1.3 & 5.0 & 0.6 & -1.8 & 4.0 & 11.4 \\
\hline Clerks & 5.8 & -3.3 & -0.9 & 2.4 & -1.5 & -4.5 & -4.7 & 2.5 & -9.8 & 5.4 \\
\hline $\begin{array}{l}\text { Service workers, shop } \\
\text { and market sales } \\
\text { workers }\end{array}$ & 7.1 & 2.3 & 3.5 & 1.5 & 14.9 & 18.1 & 7.0 & -1.6 & 53.8 & 10.6 \\
\hline $\begin{array}{l}\text { Skilled agricultural and } \\
\text { fishery workers }\end{array}$ & 4.3 & -0.2 & 5.9 & 2.4 & 5.0 & -9.1 & 4.5 & 3.0 & 11.2 & 4.8 \\
\hline $\begin{array}{l}\text { Craft and related trade } \\
\text { workers }\end{array}$ & 21.7 & 1.7 & -0.4 & 0.1 & -2.3 & -5.1 & -1.5 & -0.1 & -7.4 & 19.7 \\
\hline $\begin{array}{l}\text { Plant and machine } \\
\text { operators }\end{array}$ & 17.4 & -0.6 & -1.3 & -2.0 & -10.0 & -10.0 & -4.8 & -2.1 & -27.4 & 12.7 \\
\hline Elementary occupations & 7.7 & 3.5 & 3.2 & 1.1 & -2.5 & 10.6 & 6.4 & -2.1 & 21.4 & 9.1 \\
\hline Extensiveness of change & & 1.9 & 1.8 & 1.3 & 4.3 & 7.7 & 3.6 & 1.7 & 15.8 & \\
\hline
\end{tabular}

Note:First and last columns (Shares in 1989 and 1995) show the percentage of wage earners in each occupation in total employment. The middle columns ("Change in shared, \%") show December to December annual and all period (1988-95) percentage changes in occupational shares. The category "armed forces" has less than 20 respondents. The last column, "Extensiveness of change" captures the extent of the changes: it is the (weighted) average of the absolute values of changes in shares. 


\section{Appendix Table II}

\section{Variables definitions}

\section{Variable name}

Returns to current occupation

Returns to alternative occupations

Work Experience

Firm tenure

Gender

Ethnicity

Skills transferability index

\section{Variable definition}

Returns to current occupation are obtained from a regression of log wages on gender, level of education (seven categories), sector of activity, firm ownership, firm location, occupation dummies (two-digit level), age, and occupation dummies interacted with age. The returns to current occupation are calculated as the sum of the coefficient on the occupational dummy with the coefficient on age interacted with the relevant occupation times the age of the worker.

Returns to current occupation are obtained from a regression of log wages on gender, level of education (seven categories), sector of activity, firm ownership, firm location, occupation dummies (two-digit level), age, and occupation dummies interacted with age. The returns to alternative occupation are calculated as the weighted average of the returns to all other occupations where the weights are the probability of actual occupational switches in the previous period.

Actual number of years at work, divided by 100 .

Actual number of years with current employer, divided by 100

Dummy variable for gender, female $=1$.

Dummy variable for ethnicity, Estonian=1.

Skills transferability index (STI) is calculated as follows:

$$
S T I_{q}=1-\frac{\sum_{j=1}^{J}\left(N_{q, j}-\frac{N_{q}}{J}\right)^{2}}{N_{q}^{2}}
$$

where $\mathrm{J}$ is the number of occupation categories, $N_{q}$ is the number of workers with qualification $q$, and $N_{q, j}$ is the number of workers with qualification $q$ in occupation $j$. This index is equal to 1 for a qualification that is uniformly distributed among occupational categories but is less than one otherwise. 


\section{Appendix Table III \\ Determinants of Occupational Mobility (Probit estimates): Sensitivity Analysis Using Returns based on Future Wages to Assess Gender and Ethnicity Issues}

\begin{tabular}{|c|c|c|c|c|c|}
\hline \multicolumn{6}{|l|}{ Panel A: Males } \\
\hline \multirow{3}{*}{$\begin{array}{l}\text { Returns to current } \\
\text { occupation }\end{array}$} & 1990 & 1991 & 1992 & 1993 & 1994 \\
\hline & $.054^{*}$ & -.037 & $-.096 * *$ & $-.084^{*}$ & $-.109^{* * *}$ \\
\hline & $(.031)$ & $(.034)$ & $(.040)$ & $(.044)$ & $(.032)$ \\
\hline \multirow{2}{*}{$\begin{array}{l}\text { Returns to alternative } \\
\text { occupation }\end{array}$} & $-.097 * * *$ & .047 & .064 & .075 & .061 \\
\hline & $(.026)$ & $(.035)$ & $(.047)$ & $(.071)$ & $(.068)$ \\
\hline \multirow{2}{*}{$\begin{array}{l}\text { Skills transferability } \\
\text { index }\end{array}$} & $-.049 * *$ & -.038 & .022 & .007 & $-.053^{*}$ \\
\hline & $(.024)$ & $(.023)$ & $(.030)$ & $(.031)$ & $(.027)$ \\
\hline \multirow[t]{2}{*}{ Experience } & .126 & -.211 & -.011 & $-.307 * * *$ & $-.258^{* * *}$ \\
\hline & $(.122)$ & $(.137)$ & $(.181)$ & $(.115)$ & $(.065)$ \\
\hline \multirow[t]{2}{*}{ Firm tenure } & $-.365^{* * *}$ & $-.314^{* * *}$ & $-.149^{* *}$ & $-.271^{* * *}$ & $-.259^{* * * *}$ \\
\hline & $(.070)$ & $(.076)$ & $(.086)$ & $(.092)$ & $(.097)$ \\
\hline \multirow[t]{2}{*}{ Dummy: Estonian=1 } & -.008 & .004 & .017 & $.027 *$ & $.033^{* *}$ \\
\hline & $(.010)$ & $(.011)$ & $(.012)$ & $(.014)$ & $(.014)$ \\
\hline Log likelihood & -743.55 & -839.75 & -926.35 & -950.02 & -908.24 \\
\hline $\begin{array}{l}\text { Number of } \\
\text { observations }\end{array}$ & 2979 & 2947 & 2784 & 2603 & 2534 \\
\hline \multicolumn{6}{|l|}{ Panel B: Females } \\
\hline & 1990 & 1991 & 1992 & 1993 & 1994 \\
\hline \multirow{2}{*}{$\begin{array}{l}\text { Returns to current } \\
\text { occupation }\end{array}$} & -.010 & -.011 & .018 & $.121 * * *$ & .052 \\
\hline & $(.029)$ & $(.029)$ & $(.046)$ & $(.042)$ & $(.033)$ \\
\hline \multirow{2}{*}{$\begin{array}{l}\text { Returns to alternative } \\
\text { occupation }\end{array}$} & -.0002 & .016 & .048 & .013 & .081 \\
\hline & $(.0301)$ & $(.034)$ & $(.048)$ & $(.072)$ & $(.061)$ \\
\hline \multirow{2}{*}{$\begin{array}{l}\text { Skills transferability } \\
\text { index }\end{array}$} & .022 & $-.037 *$ & -.013 & $-.049^{*}$ & .009 \\
\hline & $(.027)$ & $(.019)$ & $(.031)$ & $(.028)$ & $(.026)$ \\
\hline \multirow[t]{2}{*}{ Experience } & -.052 & -.101 & $-.322 *$ & .104 & $-.288 * * *$ \\
\hline & $(.114)$ & $(.119)$ & $(.173)$ & $(.107)$ & $(.063)$ \\
\hline \multirow[t]{2}{*}{ Firm tenure } & $-.191 * * *$ & $-.109 *$ & $-.212^{* * *}$ & $-.245^{* * *}$ & $-.203^{* *}$ \\
\hline & $(.061)$ & $(.062)$ & $(.077)$ & $(.081)$ & $(.089)$ \\
\hline \multirow[t]{2}{*}{ Dummy: Estonian=1 } & -.008 & -.006 & .001 & .005 & .017 \\
\hline & $(.009)$ & $(.009)$ & $(.013)$ & $(.013)$ & $(.012)$ \\
\hline \multirow{2}{*}{$\begin{array}{l}\text { Log likelihood } \\
\text { Number of } \\
\text { observations }\end{array}$} & -624.56 & -573.82 & -783.23 & -715.72 & -624.29 \\
\hline & 2849 & 2720 & 2467 & 2285 & 2197 \\
\hline \multicolumn{6}{|c|}{$\begin{array}{l}\text { Note: Not shown: dummies for education (primary, basic, secondary, specialized secondary, higher and } \\
\text { academic degree), for sector (primary, secondary and tertiary), for ownership (private, state and co-operative), } \\
\text { and for location (town and countryside). Occupational mobility basis for comparison is "not switching" } \\
\text { (assigned value } 0 \text { ). Standard errors (in parentheses) are heteroscedastic-consistent, } * * * \text { denotes significant at } \\
\text { the } 1 \% \text { level; ** denotes significant at the } 5 \% \text { level; and * denotes significant at the } 10 \% \text { level. }\end{array}$} \\
\hline
\end{tabular}

